\title{
Ethno-Botanical Uses of Ugandan edible wild fruit species
}

\author{
Christine O. Onen ${ }^{1,}{ }^{*}$, Hannington Oryem-Origa ${ }^{2}$ \\ ${ }^{1}$ Gulu University, P.0 Box 166, Gulu University, +0471 Gulu, Uganda \\ ${ }^{2}$ Makerere University, Wandegeya, Makerere, P.O. Box 7062, Kampala, Uganda
}

Received: 27 October 2017

Accepted: 23 November 2017

Published online: 30 December 2017

\begin{abstract}
Edible wild fruit tree species are known to provide enormous products and services to several rural communities worldwide. Products derived from such edible wild fruit tree species and related conservation issues are not adequately documented. The objectives of this study were to document the uses/products derived from five most preferred edible wild fruit tree species of Gulu district; how their products are harvested; how they are locally managed; if there are any constraints to cultivation and local strategies for conservation. The five edible wild fruit species used in this study (Vitellaria paradoxa Gaertn, Vitex doniana Sweet, Borassus aethiopum Mart, Tamarindus indica L. and Annona senegalensis Oliv.) were earlier identified from household heads in Gulu district as most preferred. Data on these were collected using questionnaires, interview guides, field visits, home observation and photography. The main uses and products which were established included fruits, fuel-wood, charcoal, medicinal, timber among others. Modes of harvests varied with each product. No management system was in place for any fruit tree species. Wild fruits have several products not yet documented. Willingness to cultivate these fruit trees is low. It is, therefore, important to raise awareness on the demises of mismanaging these tree species, set and implement adequate conservation measures.
\end{abstract}

Keywords: Conservation, uses, Edible wild fruit trees

\section{Introduction}

Many rural African households depend on natural resources for subsistence (Sunderlin et al. 2005; Schreckenberg et al. 2006). In this context, edible wild fruit tree species are very important, in that they provide both food and nonfood products (such as firewood and charcoal) which contribute substantially towards household livelihoods, especially during times of economic hardship (Iranbahsh 2009). Fruits, in general are important for a balanced diet, serving as food supplements and providing important vitamins, minerals and protein while edible wild fruits, in particular are widely consumed during famines and/or periods of food shortages (Adepoju 2009).

Jama et al. (2008) noted that many edible wild fruit trees could be integrated into dryland farming systems in sub-Saharan Africa to support income and nutritional security. Many inhabitants in South African rural villages are known to make use of wild resources from communal areas around their homes, arable land and residential plots (High and Shacleton 2000) to provide products such as vegetables, fuel wood, furniture, making baskets and mats, toothbrushes, medicines, and edible fruits. Kabala et al., (2009) noted that many inhalants previously believed that indigenous fruits do not play a major role in contributing to rural livelihoods. Consequently, their subsistence and commercial uses

\footnotetext{
${ }^{*}$ Corresponding author: C. O. Onen

e-mail: chroryonen@gmail.com
} 
were overlooked. This resulted to lack of adequate data on indigenous fruit income related terms without which influential policy debate to encourage their usage was not possible (Schreckenberg et al. 2006). However the belief that such resources were unimportant is now widely held to be mistaken. Syampungani et al. (2009), for example, acknowledge that $70 \%$ of the energy consumed in South Africa is derived from trees in form of fuelwood or charcoal derived from Miombo woodland. Similarly, Shacleton and Schacleton (2004) noted that in South Africa wild resources are important in complementing the diverse livelihood strategies within a household, despite the fact that the community derives only a small cash income from trade in wild plants.

In a study conducted by Oryema et al. (2013), several edible wild fruit species were identified as being consumed in large quantities and as contributing significantly towards the livelihoods of the local community. These fruit species were noted by those researchers as having a wide range of uses in rural communities, contributing to food security, and providing for needs such as livestock feed, income and energy. However, their precise uses were not fully documented. Such documentation is however urgently required, as these species are at considerable risk of over-exploitation which threatens local livelihoods as the resources are lost (Hamilton and Hamilton 2006). Over-extraction of wild fruit trees does not only result in the loss of those specific species, but also in the loss of other species as the forest is cleared leading to rapid decreases in the number of some less common species (Hamilton and Hamilton 2006). If indiscriminate harvesting continues, many edible wild fruit species will disappear without their useful products and the practices associated with them are documented.

A study was therefore designed and undertaken in Gulu district, Uganda to provide a detailed understanding of the products derived from edible wild fruit species, and to encourage the sustainable use of this valuable resource. The study objectives were (i) to document the uses/products derived from the five most preferred edible wild fruit tree species in Gulu district and how each product is harvested, (ii) to identify the challenges that local communities face in managing this resource and (iii) to identify what conservation strategies communities are using to manage edible wild fruit tree species as a resource.

To achieve these objectives, this study focused on only five edible wild fruit species in Gulu District previously identified as "most preferred" for their edible wild fruits (Oryema et al. 2013). Questionnaires and interview guides were designed and administered to different households during a field survey to obtain required data.

\section{Materials and Methods}

Ethical clearance was obtained from the Research and Ethics Committee of the Faculty of Medicine, Gulu University and the Uganda National Council for Science and Technology (UNSCT) before the commencement of the study. Two-day training for field assistants was then conducted to emphasize on procedures for participants' identification, questionnaire administration, recording of responses, respect for participants and ethical considerations.

The tools used for data collected in this study included questionnaires and interview guides and these were pre-tested and piloted prior in Pader District in Uganda to enhance precision of the planned research. The actual study was conducted in six randomly selected sub-Counties of Gulu district and included Patiko, Paicho, Awach, Ongako, Bobi and Lalogi sub-counties of the two counties (Aswa and Omoro) of Gulu District, Uganda.

A total of 350 respondents obtained using using the formula developed by Keish (1965) were chosen in cluster sampling procedures. In this procedure, the local councillor one (LC1s) of the respective villages in the study sub-counties identified a presumed centre of their villages from where the household sampling by the researchers started. The team then moved strictly to the right hand side instantly identifying households. However, only willing household heads were interviewed until when 
the planned 350 respondents were covered from the thirty three Parishes of the six Sub-counties. The study included both female and male household heads of ages 15 years and above. The starting age of 15 years was chosen because the over 20 years of insurgency between the Lord Resistance army and the Government of Uganda between 1986-2006 in Northern Uganda left so many households with children as the heads of families. These children were exposed to a number of social and livelihood activities at a tender age thus could have encountered several indigenous fruit species. The tools used in the data collection were questionnaires, and interviews using question guides. These major tools were administered by the researchers and took one and half hours per respondent. However, other information which was obtained through observations, informal conversations, and interactions outside designated interview time were all were recorded and then later transcribed.

The five preferred edible wild fruit trees of focused (Vitellaria paradoxa Gaertn, Vitex doniana Sweet, Borassus aethiopum Mart, Tamarindus indica L. and Annona senegalensis Oliv.) were previously identified by Oryema et al. (2013). Photographs of these fruit species and products were taken during the field visits for inclusion in the final research report.

Data collection focused on respondents' personal experiences on (i) the different products (uses) and services obtained from the preferred fruit species ii) How each of products (uses) and services were harvested; iii) status of the preferred species in the respondents' gardens (whether they were spared, planted or not planted) (iv) the challenges that local communities face in managing this resource and (v) Conservation strategies that the communities are using to manage edible wild fruit tree species as a resource.

Questionnaires responses were checked for correctness and entered in Microsoft Excel (Version 7) before exporting to STATA 12 (Stata Corp. LP, College Station, and Texas, USA) for analysis. The results of the analysis were presented in percentages in forms of tables and figures. All information obtained using the interview guides and conversations were transcribed and recorded as narratives.

\section{Results}

\subsection{Socio-demographic characteristics of respondents}

The respondents possessed low levels of formal education, with the majority only having primary level education (Tab. 1). Majority were married, and depended on crop farming as their main source of livelihood.

Tab. 1 Education background and livelihood characteristics of the respondents $(n=350)$.

\begin{tabular}{lc}
\hline & Percentage \\
\hline Education & 27 \\
No education & 62 \\
Primary & 11 \\
Secondary and vocational & \\
Sources of livelihood & 72 \\
Farming only & 20 \\
Farming and retail business & 7 \\
Farming and charcoal making & 2 \\
Farming and brick making & \\
\hline
\end{tabular}

\subsection{Products and uses of the preferred edible wild fruit tree species (PEWFTS)}

All PEWFTS were treasured highly for their fruits, fuel-wood, timber and construction materials (Tab. 2). Borassus aethiopum produced neither charcoal nor medicinal products. Craft materials were obtained from three species: Vitex doniana, Vitellaria paradoxa and B. aethiopum 
C. O. Onen and H. Oryem-Origa

Tab. 2 Products (Uses) and other ecosystem services derived from the preferred edible wild fruit tree species (PEWFTs).

\begin{tabular}{|c|c|c|c|c|c|c|c|c|}
\hline \multirow{2}{*}{$\begin{array}{l}\text { Scientific } \\
\text { (local ) } \\
\text { names of the } \\
\text { PEWFTs }\end{array}$} & \multicolumn{8}{|c|}{ Percentages (\%) responses to products derived from each PEWFTs } \\
\hline & $\begin{array}{l}\text { Edible } \\
\text { fruits }\end{array}$ & $\begin{array}{l}\text { Fuel- } \\
\text { wood }\end{array}$ & Charcoal & Timber & Medicines & $\begin{array}{c}\text { Ecosystems } \\
\text { services }\end{array}$ & $\begin{array}{c}\text { Crafts } \\
\text { materials }\end{array}$ & $\begin{array}{c}\text { Other } \\
\text { products }\end{array}$ \\
\hline $\begin{array}{l}\text { Vitex } \\
\text { doniana } \\
\text { Sweet } \\
\text { (Oywelo) }\end{array}$ & 33 & 32 & 17 & 7 & 4 & 4 & 1 & 9 \\
\hline $\begin{array}{l}\text { Vitellaria } \\
\text { paradoxa } \\
\text { (Yaa) }\end{array}$ & 51 & 31 & 7 & 4 & 3 & 4 & 1 & 23 \\
\hline $\begin{array}{l}\text { Borassus } \\
\text { aethiopum } \\
\text { (Tugu) }\end{array}$ & 35 & 29 & 0 & 19 & 0 & 8 & 9 & 9 \\
\hline $\begin{array}{l}\text { Tamarindus } \\
\text { indica L. } \\
\text { (Cwa) }\end{array}$ & 23 & 21 & 7 & 8 & 8 & 35 & 0 & 0 \\
\hline $\begin{array}{l}\text { Annona } \\
\text { senegalensis } \\
\text { Oliv. } \\
\text { (Obwolo) } \\
\end{array}$ & 20 & 20 & 20 & 14 & 15 & 9 & 0 & 0 \\
\hline
\end{tabular}

\subsection{Narrated uses of the some PEWFTS}

\section{a) Borassus aethiopum}

Other than the fruits ( Fig. 1A), the dry leaf petioles of B. aethiopum fruit tree species (Fig. 1B) were reportedly used as fuel-wood mainly for roasting fermented dough for making a local brew known as Lujutu among the Acholi tribe (Fig. 1C). The dry leaves were used for weaving mats while the leaf veins provided materials for weaving baskets, winnowers and other household decorations (Fig. 1D). Its fresh leaves (Fig. 1E) were used for construction of huts.

The dry seeds (Fig. 1G) were recognized for providing good a source of heat during campfire locally known as Wang Oo (Fig. 1F) and also for cooking and heating in different households. The stems were cut into pieces and made hollow for use as local beehives locally known as "Bong Kic" (Fig. 1H). The mature stems of this tree was split into pieces of timbers (Fig. 1I) and used for construction of both temporary and semi- permanent buildings, and for making furniture such as local benches. The timbers were also used in making local bridges and for fencing homes and kraals.

The dried inflorescence of the male trees and the stem cortex were burnt into ashes, and then filtered locally into filtrates locally called "Kado atona" in the Acholi language and used to catalyze the cooking of many local dishes. The fruit trees were also treasured as ornamentals hence provides the aesthetic values to the localities where they exist.

The hypocotyls (i.e. the young roots of the seedlings) (Fig. 1J) were reportedly boiled or roasted, peeled and eaten. The endosperms (Fig. 1K) were obtained from the old seeds by splitting them open and then eaten. 


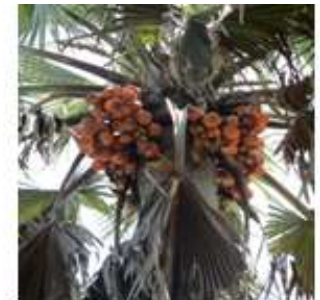

(A)

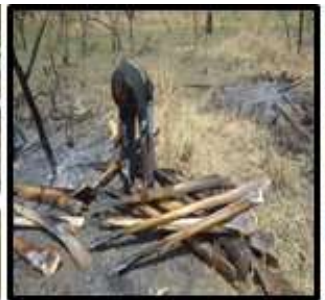

(B)

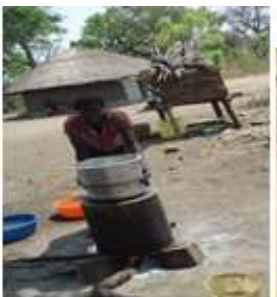

(C)

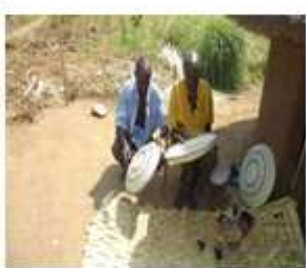

(D)

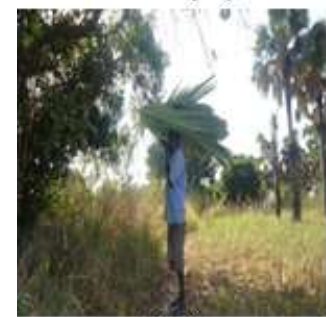

(E)

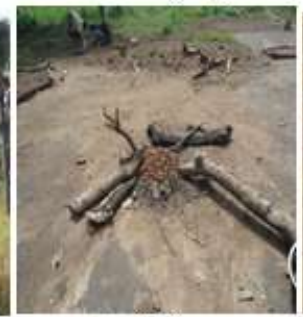

(F)

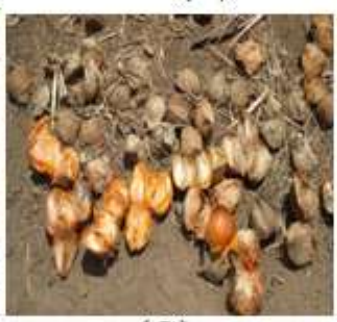

(G)

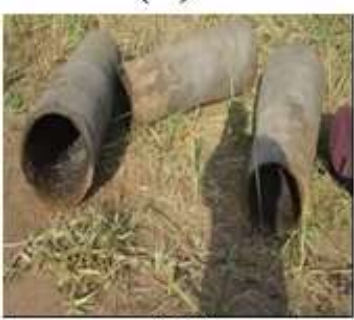

(H)

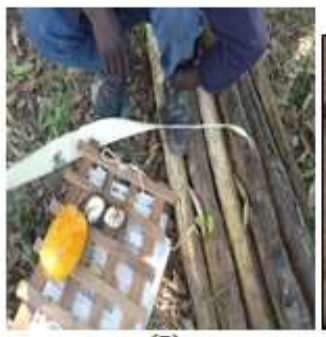

(I)

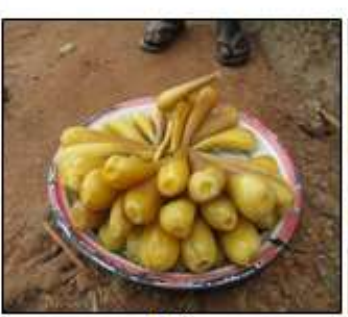

(J)

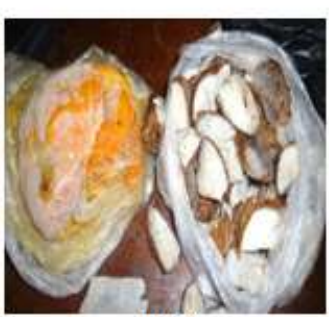

(K)

Fig. 1A-K Products obtained from B. aethiopum fruit tree species (A: fruits; B: the dry petioles; C: Lujutu; D: winnowers and a mat; E: fresh leaves; F: dry seed coat at Wang Oo; G: the seeds; H: local beehives; I: pieces of timbers from srems; J: hypocotyls; K: endosperm).

\section{b) Vitellaria paradoxa}

Vitellaria paradoxa fruits were reported as eaten fresh (Fig. 2A). In addition, the fruit pulps were made into pulp cakes known locally as Poki (Fig. 2B). The milky saps from stem barks (Fig. 2C) and root barks were reportedly used for treating diarrhea. In addition, the sap was mentioned as used for mending broken items like jerry cans, cracked drums, pots and gourds. Mulched leaves were treasured for manure.

The Shea butter was valued for improving palatability of local dishes; complementing traditional rituals like celebrating the birth of twins; and also smeared on the body as a moisturizer. After extracting the Shea butter from the dry seeds (Fig. 2D), the resulting black residues which is commonly known as Cet Yaa was notably used for trapping small wild animals such as edible rats and squirrels (Anyeri and Ayita respectively in Acholi language, Uganda). Furthermore, the residue is smeared on handles of hoes, knives, machetes and mud walls to prevent weevils and termites infestations respectively. The wood from this tree species also produced quality charcoal and fuel-wood (Fig. 2E and Fig. 2F, respectively). This species was also noted to produce strong poles known locally as Wir, Guti and Lakar in Acholi language for supporting grass-thatched huts (Fig. 2G)". Furthermore, the wood was known for its use in making mortars and pestles as well as handles of hoes, knives and machete. 


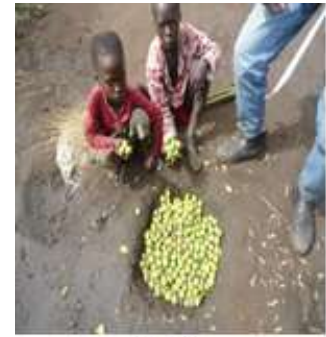

(A)

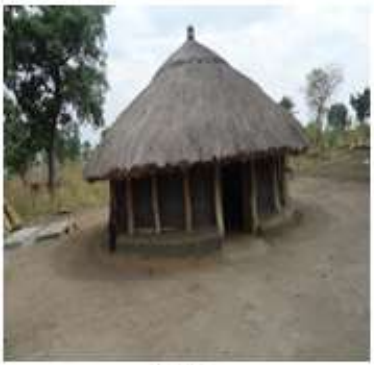

(E)

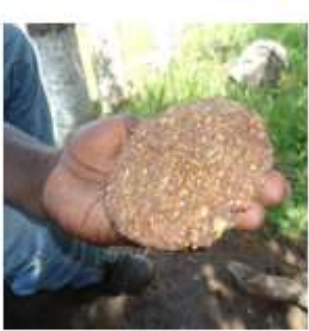

(B)

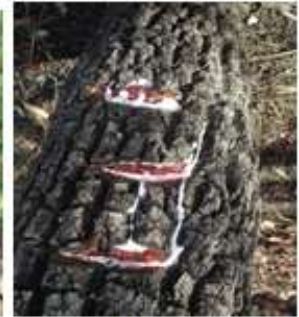

(C)

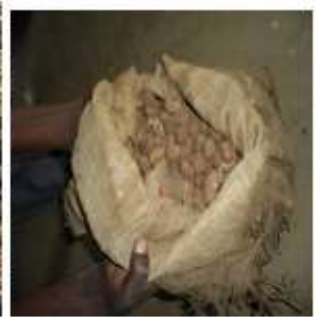

(D)

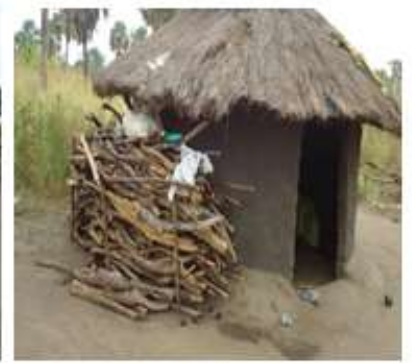

(F)

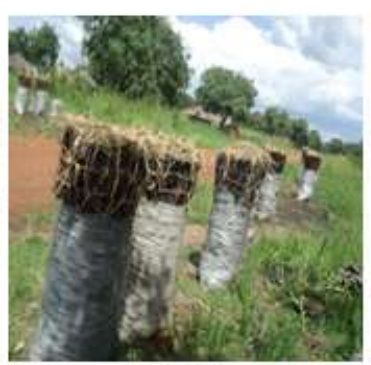

(G)

Fig. 2A-G Products from V. paradoxa fruit tree (A: fresh fruits; B: dried pulp cake(Pokoi); C: milky sap; D: preserved seeds; E: sacs of charcoal; F: piles of firewood; G: a hut with supporting poles).

\section{c) Vitex doniana}

Vitex doniana species was reported to produce light timber for making windows, door frames, and local musical instruments such as drums, thumb pianos and harps (bul, lukeme, and Adungu respectively in Acholi language. These instruments are commonly used in Acholi traditional dances. Its leaf extracts are known for treating coughs in local chickens, while the fruits (Fig. 4B) commonly known as black sweet fruits are highly consumed by members of the community for their sweetness and nutrious values.

\section{d) Tamarindus indica}

Tamarindus indica fruit tree was appreciated for providing dense canopy of shade on compounds for relaxation, and also functions as wind breaks. Its fruits were reportedly dried and preserved in polythene bags (Fig. 3A). When the fruits are smashed, the extracts are either drunk directly, or mixed in porridge or black tea to improve their palatability (Fig. 3B). Its leaves when chewed improve any unpleasant conditions of the mouth.

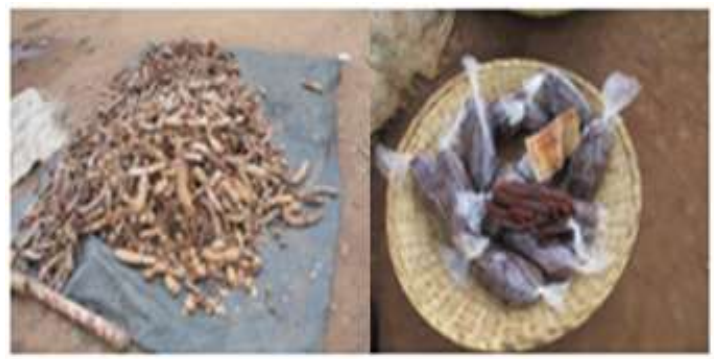

(A)

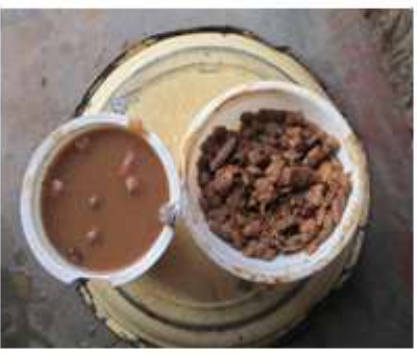

(B)

Fig. 3A-B Fruits (A) and extracts (B) of T. indica. 
C. O. Onen and H. Oryem-Origa

\section{e) Annona senegalensis}

The large leaves of A. senegalensis are used to protect the local people from the scorching sunshine or rain drizzles, and also valued for treating stomach discoid. Meanwhile the fruits when ripe are eaten pleasantly (Fig. 4A).

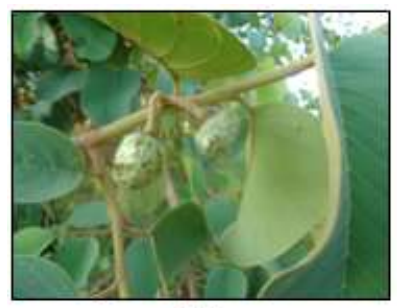

(A)

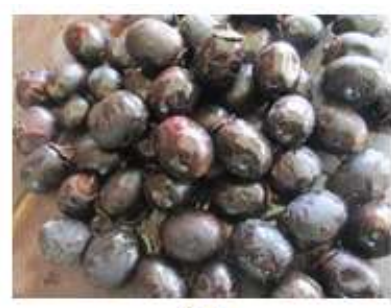

(B)

Fig. 4A-B Leaves and unripened fruits of A. senegalensis (A) and Vitex doniana fruits (B).

\subsection{The different ways by which products are harvested from the Preferred Edible Fruit Tree Species (PEWFTs)}

Products were harvested differently (Tab. 2). Most fruits were picked after falling naturally on the ground. Charcoal and timbers were obtained by felling down the whole tree.

Tab. 3 The different ways by which products are harvested from the Preferred Edible Fruit Tree Species (PEWFTs).

\begin{tabular}{|c|c|c|c|c|c|c|c|c|c|c|c|c|}
\hline \multirow[t]{3}{*}{ PEWFTS } & \multicolumn{12}{|c|}{ Ways by which the different products are harvested $(n=350)$} \\
\hline & \multicolumn{2}{|c|}{ Fruits } & \multicolumn{3}{|c|}{ Fuel-wood } & \multirow{2}{*}{$\begin{array}{c}\text { Charcoal } \\
\text { CWT }\end{array}$} & \multirow{2}{*}{$\begin{array}{c}\text { Timber } \\
\text { CWT }\end{array}$} & \multicolumn{3}{|c|}{ Medicines } & \multicolumn{2}{|c|}{ Craft/Arts } \\
\hline & FFR & FHT & $\mathrm{CDB}$ & CDP & CWT & & & PL & ERB & ESB & CWT & PDP \\
\hline $\begin{array}{l}\text { Vitex. } \\
\text { doniana }\end{array}$ & 73 & 27 & 65 & NP & 35 & 39 & 11 & 10 & 2 & 1 & 100 & NP \\
\hline $\begin{array}{l}\text { Vitellaria. } \\
\text { paradoxa }\end{array}$ & 98 & 2 & 100 & NP & NP & 26 & 8 & 5 & 0 & 2 & 100 & NP \\
\hline $\begin{array}{l}\text { Borassus. } \\
\text { aethiopum }\end{array}$ & 97 & 3 & NP & 100 & NP & $\mathrm{NP}$ & 51 & $\mathrm{NP}$ & NP & NP & & 100 \\
\hline $\begin{array}{l}\text { Tamarindus. } \\
\text { indica }\end{array}$ & 41 & 59 & 82 & $\mathbf{N P}$ & 18 & 18 & NP & 6 & NP & NP & NP & NP \\
\hline $\begin{array}{l}\text { A. } \\
\text { senegalensis }\end{array}$ & 9 & 91 & 45 & NP & 55 & 54 & NP & 2 & NP & 9 & NP & NP \\
\hline
\end{tabular}

\subsection{Conservation practices for the Preferred Edible Wild Fruit Tree Species (PEWFTS)}

More respondents preferred to retain the PEWFTs on their fields than to plant them (Fig. 5). Only B. aethiopum and T. indica were planted.

\subsection{Constraints hindering the promotion of the PEWFTS}

Most respondents (>60\%) believed that the PEWFTs are still in plenty in the wild (Fig. 6). This is followed by those (20\%) who think PEWFTS only thrive in their original habitat and then $10 \%$ regarded the products as of low market values.

\subsection{Suggested Strategies towards the conservation of the PEWFTs}

Respondents suggested community sensitization (30\%) as the most suitable means to promote PEWFTs development (Tab. 4). This is followed by training on seedling raising, management and 
C. O. Onen and H. Oryem-Origa

planting (28\%) and the least were those who require information on the nutrient compositions of the preferred fruits and related edible product (3\%).

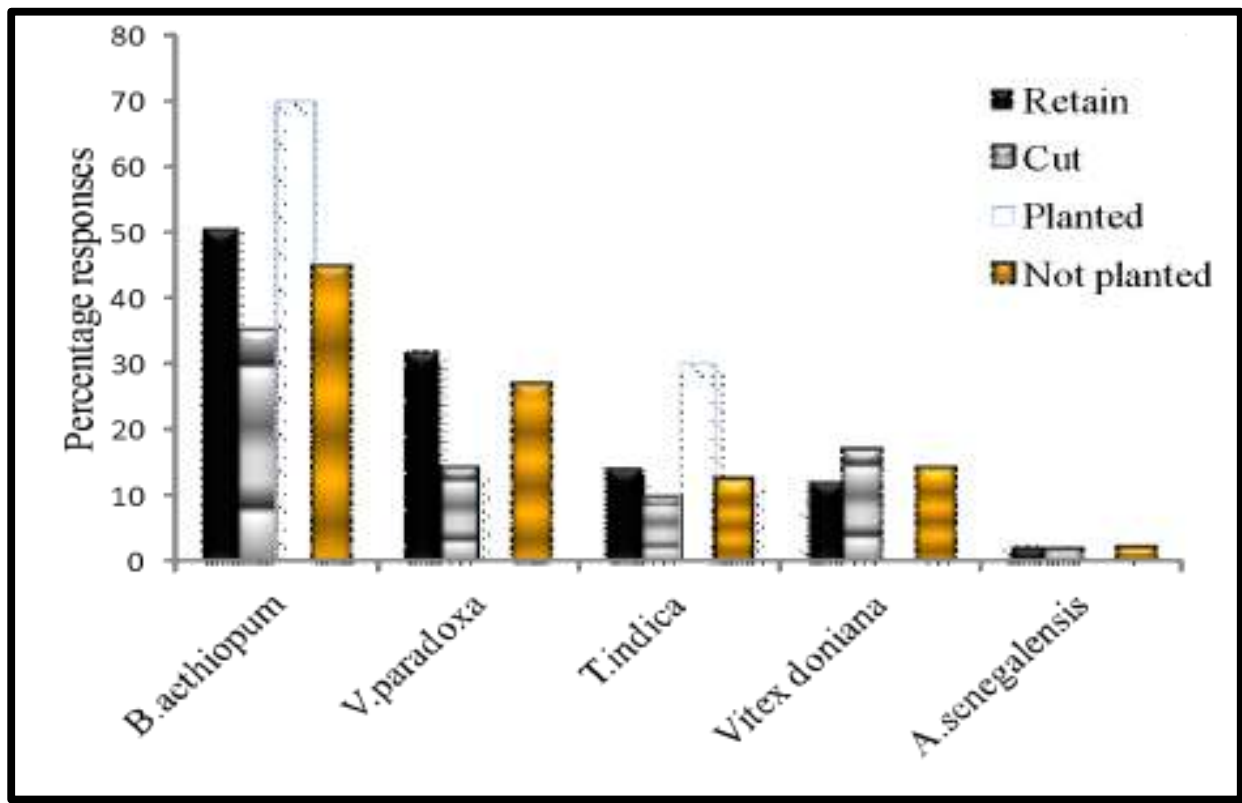

Fig. 5 Conservation practices for the Preferred Edible Wild Fruit Tree Species (PEWFTs).

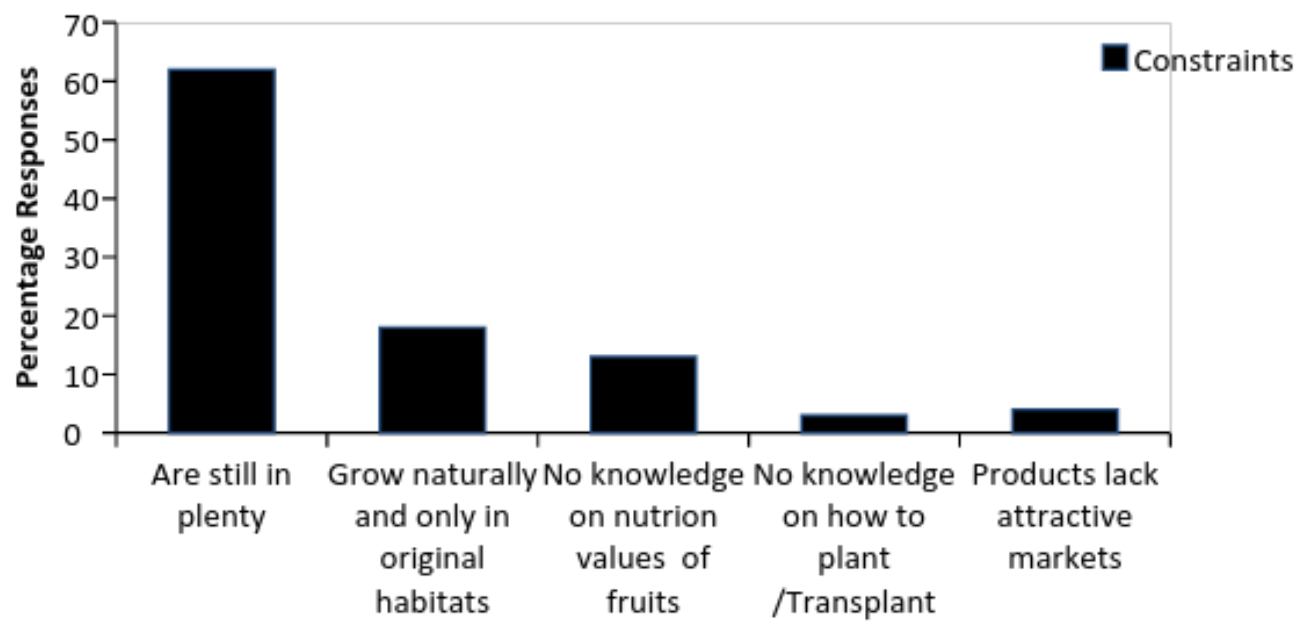

Fig. 6 Constraints to the promotion of PEWFTs.

Tab. 4 Suggested actions for conserving the Preferred Edible Fruit Tree Species.

\begin{tabular}{l|c}
\hline Suggested Actions & Per cent \\
\hline Community sensitization & 30 \\
Train on seedling raising and & 28 \\
management & \\
Enact and implement the by-laws & 21 \\
$\quad$ on multipurpose trees & 7 \\
Regulate timber harvesting & 5 \\
Control bush burning & 4 \\
Clear around priority fruit trees & 3 \\
Provide information on nutrient & \\
\hline compositions of the wild fruits & \\
\hline
\end{tabular}




\section{Discussion}

The products and uses of the PEWFTS as shown in this study (Tab. 2), (Fig. 1 -4) indicate the outstanding knowledge of the respondents about the uses of the edible wild fruits in their vicinity. Since these respondents are farmers, they interact so frequently with the wild fruit tree species and use them in various ways. They are also of low education background (Tab. 1) hence natural resources become the obvious sources of livelihood (Aguilar and Condit 2001; Tabuti et al. 2003) in the rural areas where live.

The fruits of all these PEWFTS are treasured and highly consumed due to the different characteristics which they possess. The fruits of B. aethiopum for example are highly eaten for their flavours, and the thick juice which is obtained from the fruit as it is being chewed. These fruits as reported by some authors (Ali et al. 2010; Oryema et al. 2016) contain good nutrients compositions. The fibrous nature of the fruits on the other hand can clean the teeth when chewed. This can be very helpful to some members of the community who take several days without cleaning up their mouth or brushing their teeth. However, among the Bassari community in Guinea, these fruits are used for making wine (Sambou, et al. 2002), which is a good source of income for the community. Tamarindus indica fruits on the other hand are widely valued for their sour taste (Van der Stege et al. 2011; Oryema et al. 2015) which when prepared as in Fig. 3B and mixed with porridge can improve on its palatability. Therefore, if well preserved (Fig. 3A), they can last for some times and consumed at any time yearround as desired by the communities. Similarly, from this study both the fresh and dried cakes of the fruits of Vitellaria paradoxa (Fig. 2A - B) respectively are very essential to the community in providing valuable nutrients (Oryema et al. 2016). This can supplement nutrients in nutrient deficient conditions in the community.

Charcoal and fuel-wood as established in this study are the major sources of energy in this community. They are highly used in both the rural and urban areas. These products are substantially consumed for cooking, lighting, ironing clothes and heating water (Petheram et al. 2006). Fuel wood is highly demanded at camp places called Wang Oyo among the Acholi tribe. Furthermore, they are used in a number of industries and institutions such as bakeries, schools, hospitals and brick making industries. Since most charcoal burners and fuel-wood sellers are of low education back (Kalema, 2010), these are then automatically treasured sources of income. Consequently, this puts the trees at risk of extinction as harvest increases.

Regarding the hypocotyls locally known as Ocwiji in Acholi tribe in Gulu district, and the endosperms, unless otherwise stated, the eating of these products are reported for the first time in Uganda in this study. The economic potentials of the hypocotyls over the other values of B. aethiopum products such as mats have been highly recognized in Adamawa State in Nigeria (Jatau 2008), a similar establishment in Gulu district. Barminas et al. (2008) noted that, starches derived from the hypocotyls can be applied in dishes, baby food, and a variety of new food products. Therefore, if these application could be replicated in Gulu district, the number of malnutrition cases could be reduced.

Though the endosperms appeared as one useful products of B. aethiopum, its consumption is mostly by the rural children who are often left at home for a long time without food. They provide good supplements hence are a good source of nutritious snacks. Therefore, they provide nutrients which can aid in the reduction of malnutrition rates and prevalence of underweight children leading to the achievement of the Millennium Development Goals (Schreckenberg et al. 2006).

The local beehives (Fig. 1E) to a larger extent enhance income to this community from both the direct sales of this items and indirectly sales of the honey. Honey is one very important product of apiculture to the community (Yédomonhan et al. 2012). The availability of these local beehives therefore reduces financial constraints of buying modern beehives which are often expensive and unaffordable by many poor households in the community. 
The local timbers (Fig. 1F) on the other hand substitute the very expensive timbers from timber trees which are often very expensive hence unaffordable by most members of the community. Those types of timbers help the community to upgrade from grass thatch houses to construction of semipermanent houses. Eventually this enables them to live in descent houses to improve their hygienic conditions, security, and protects from rain a (Petheram et al. 2006).

In Gulu district the staminates of the flowers are a source of sodium carbonates but in Senegal it is used in the treatment of venereal diseases, and when mixed with Shea butter it heals wounds (Sambou et al. 1992). The Sodium carbonates catalyzes the cooking of many sauces among others vegetables hence indirectly promoting vegetable consumptions. Thus, this reduces nutrient deficiencies (Ekesa et al. 2009) in the body.

The community of Gulu District attaches so many values to the enormous products from Vitellaria paradoxa. The Shea butter for example,provides palatability to many local dishes, and has been emphasized by many authors (Maranz et al. 2003). As noted, the resulting black residue after the extraction of the Shea butter traps edible wild animals. It is thus a useful source of delicacies and animal proteins to the local community. In Nigeria this residue is referred to as the seed cake, and is very useful in making livestock feeds and also used in poultry industries (Ugese et al. 2010; Dei et al. 2007), a usage that can also be replicated in Gulu district.

The leaves of Annona senegalensis being as a source of herbal medicine in this community, are very helpful in solving medical conditions which are normally treated locally (Oryema et al. 2010). These can also complement in many circumstances where drugs for certain ailments are not available in community health centres and may also be very expensive from drug shops and pharmacies.

Most methods used to harvest products from the PEWFTS are very destructive (Tab. 3). For example, the method used for harvesting charcoal and fuel wood demands the felling down of the whole tree. Methods can cause destruction of the roots, and slashing of the stem bark can destroy the vascular bundles resulting to death. Consequently, as the demand for those products increase, the populations of many such fruit tree species like V. paradoxa with quality products (Agea et al. 2007 and 2010) will eventually decline or disappear. this will consequently affect indirect values such as climate control, shade, manures, and habitats. Ogunleye et al. (2004) noted destruction of these trees as an act of ignorance of the functions of bio-diversities. This is also seen in Gulu District where there are no deliberate efforts made by the community to conserve any of these PEWFTS.

Although fruits are mostly picked after naturally falling on the ground, other destructive methods such as the use of stones, long stick, loop/bending or bending branches and shaking branches to dislodge the fruits are also noted. The latter methods cause a lot of destruction (Tchiegang-Megueni et al. 2001; Aditi and Kamaljit 2002) and several quality fruits that could serve in later days for nourishing hunger and/or generating income are lost. Jamnadass et al. (2011) recommends sustainable wild fruit harvesting as an important coping strategy especially during times of extreme hunger.

The status of the PEWFTS on community land is alarming. Most respondents are not positive about planting these PEWFTS (Fig. 4) rather they prefer to retain them on the garden (Okullo and Waithum 2007). From a conservation point of view, just retaining trees on the gardens is not sustainable because only a few tree stands are left on a given garden at a time and yet the demand could be high. Besides, the gardens are meant for crop production hence no respondents would allow shades of the retained trees to destroy their crops. Similarly, fruits always attract vermin animals hence if many are left where crops are growing, the vermin can in turn destroy the crops. Therefore, if the impact of conservation is to be realized, then proper domestication and conservation in the wild and homes should be enforced.

Domestication or the cultivation of the PEWFTS in Gulu District are affected by a number of constraints (Fig. 5). These are found to be similar to those reported by other authors (Okullo and Waithum 2007; Agea et al. 2010). The belief held by members of this community that PEWFTs cannot 
grow outside their natural environment trees in the wild, has greatly contributed to the low interest in domestication. Individuals continue to rely on these trees from the natural environment. Consequently, this is exposes the fruit trees to over exploitations and eventual extinctions. Lovett and Haqs (2000) noted similar reluctance especially in the planting of Shea nut trees in Ghana if it was not because of tradition. On-farm cultivation of indigenous fruit trees was noted a very small component of farming practices in Uganda (Agea et al. 2007). Rather, introduced fruit tree species are currently on high promotion by agricultural sectors hence the rapid replacement of these indigenous fruits trees. With such a belief even the edible wild fruit trees near homes are not taken care of. They are ignored hence destroyed by livestock before they can even establish themselves and grow into mature trees and yet they are capable of self regeneration and/or sprouting.

\section{Conclusion and Recommendations}

The PEWFTS have many uses and products of great values to the community of Gulu district. Modes of harvest are dependent on the products desired, but most of them are very destructive to the tree population. No local management system is in place to sustain the products from the PEWFTS. Retention of the trees on the gardens is the most preferred even when it is not sustainable. Similarly, the will to have these trees domesticated or planted in the gardens are also low due to ignorance of the potentials of the fruit trees. Therefore if these fruit trees are not well handled the their population will slowly dwindle to total depletion. This is because the future of these fruit tree species is dependent on the active involvement of the local community in the species management.

To save the situation, there is need for collaborative efforts in handling the constraints mentioned by the community and commencing on the implementation of the recommended strategies. Awareness on the predicted demise of the species destruction and the disadvantages of over exploitation without planting is also important. Feedback of all research on edible wild fruits should be given to the community to support any existing conservation efforts.

\section{Acknowledgement}

We thank Enhancing Research Capacity Project (ENRECA) Gulu University for funding this project. Appreciation also goes to Gulu University for providing adequate time for this study. DANIDA Fellowship centre is also acknowledged for all their valuable support for hosting and facilitating my stay in Denmark.

\section{References}

Adepoju TO (2009) Proximate Compositions and macronutrients of three available wild fruits in Nigeria. African Journal of Agricultural Reseach. 4(9): 889-892.

Aditi S, Kamaljit SB (2002). Harvesting techniques, hemiparasites and fruit production in two nontimber forest tree species in south India. Forest Ecology and Management. 168: 289-300

Agea JG, Obua J, Kaboggoza JRS, Waiswa D (2007) Diversity of indigenous fruit trees in the traditional cotton-millet farming system: the case of Adwari sub county, Lira district, Uganda. African Journal of Ecology. 45: 39-43.

Agea GJ, Obua J, Waiswa D, Okia AC, Okulu JB (2010) Attitudes Towards On-farm Cultivation of Indigenous Fruit Trees in Adwari Sub-Counties, Lira District, Uganda. Ethnobotanical Leaflets. 14:366-80.

Aguilar S, Condit R (2001) Use of native tree species by a Hispanic community in Panama. Economic Botany. 55 (2): 223-35.

Ali A Djibrilla Alhadji Clergé Tchiegang, Clément Saïdou (2010a) Physico-chemicproperties of palmyra palm (Borassus aethiopum Mart.) fruits from Northern Cameroon. Journal of Food Science $. .4(3): 115-119$. 
Barminas JT, Onen AI, Zaruwa MZ, Mamuru SA, Haggai D (2008) Studies on functional properties of Borassus starch from fresh germinating nuts of giginya (Borassus aethiopum) palm. Food Hydrocolloids. 2:298-304.

Dei HK, Rose SP, Mackenzie MA (2007) Shea nut ( Vitellaria paradoxa ) meal as a feed ingredient for poultry . World's Poultry Science Journal. 63(4):611-624.

Ekesa BN, Walingo MK, Abukutsa-Onyango MO (2009) Accessibility to and consumption of Indigenous Vegetables and Fruits by rural households in Matungu Division, Western Kenya. African Journal of Food and Nutrition Development (AJFAND). 9(8): 1725-1738.

Hamilton A, Hamilton P (2006) Plant conservation. An ecosystem approach. Published by Earthscan in the Uk and USA.

High C, Shacleton CM (2000) The comparative value of wild and domestic plants in home gardens of a South African rural village. Agroforestry Systems. Vol.48:141-156.

Iranbakhsh A, Ebadi M, Zare Z (2009) The contribution of indigenous fruit trees in sustaining rural livelihoods and conservation of natural resources. Journal of Horticulture and Forestry 1(1): 001006.

Kalaba FK, Chirwa PW, Prozesky H (2009) The contribution of indigenous fruit trees in sustaining rural livelihoods and conservation of natural resources. Journal of Horticulture and Forestry.1(1) pp. 001-006.

Kalema NV (2010) Diversity, Use And Resilience Of Woody Species In A Multiple Land Use Equatorial African Savanna, Central Uganda. Diss. A thesis submitted to the Faculty of Science, University of the Witwatersrand, Johannesburg, in fulfillment of the requirements for the degree of Doctor of Philosophy. Johannesburg.

Keish L. (1965) Survey. John Wiley and Sons . 1965. New York :1-50.

Langdale-Brown, Osmaston HA, Wilson JG (1964) The vegetation of Uganda and its bearing on land use. Government of Uganda Entebbe.

Lovett NP, Haq N (2000) Evidence for anthropic selection of the Shea nut tree (Vitellaria paradoxa) . Agroforestry System. 48: 273-288.

Maranz S, Kpikpi W, Wiesman Z, De Sauuveur DS, Chaplain D (2004) Nutritional values and indigenous preferences for Shea Fruits \&lt;i\&gt;(vitellaria paradoxa C.F. Gaertn F.). In African Agrofrrestry Parklands. Economics Botany. 58(4):588-600.

Ogunleye AJ, Adeola AO, Ojo PLO, Aduradola AM (2004) Impact of Farming activities on vegetation in Olokemeji Forest Reserve, Nigeria. Global Nest. The International Journal. 6(2):131-140.

Okullu BL, Waithum G (2007) Diversity and conservation of on-farm woody plants by field types in Paromo Subcounty, Nebbi District, north-western Uganda . African Journal Of Ecology. 45(3): 5666.

Oryema C, Oryem-Origa H, Nanna R (2016) Nutrient contents of the fresh pulps and dried pulp cakes of vitellaria paradoxa of Gulu District, Uganda. Pakistan Journal of Nutrition. 15, (1): 33-39.

Oryema C, Oryem-Origa H (2016) Analysis of the Fresh Pulps of Borassus aethiopum Fruits of Gulu District, Uganda. American Journal of Food and Nutrition. 4 (6): 177-181.

Oryema C, Oryem-Origa H, Nanna R (2015) Influential factors to the Consumptions of Edible Wild Fruits and Products in the Post Conflict District of Gulu, Uganda. Journal of Natural Sciences Research. 5(10): 132-143.

Oryema C, Oryem-Origa H, Nanna R (2013) Edible wild fruit species of Gulu District, Uganda. International Journal of Biology and Biological Sciences. 2(4). 068-082.

Oryema C, Ziraba RB, Omagor N, Opio A (2010) Medicinal plants of Erute county, Lira district, Uganda with particular reference to their conservation. African Journal of Ecology. 48 (2) 285-298.

Petheram L, Campbell BM, Marunda CT, Tiveau D, Shackleton S (2006) The wealth of the dry forests: can sound forest management contribute to the millennium development goals in Sub-Saharan Africa? . CIFOR Livelihood Brief No.5. Bogor, Indonesia, Center for International Forestry Research (CIFOR). 4p.

Sambou B, Goudiaby A, Ervik F (2002) Palm wine harvesting by the Bassari threatens Borassus aethiopum populations in north-western Guinea. Biodiversity and Conservation. 11 ( 7):1149-1161.

Sambou JE, Laweson EJ, Barfod A (1992) Borassus aethiopum, a threatened Multipurpose Palm in Senegal. Pricipes. 36(3): 148-155. 
C. O. Onen and H. Oryem-Origa

Schreckenberg K, Awono A, Degrande A, Mbosso C, Ndoye O, Tchoundjeu Z (2006) Domesticating Indigenous Fruit Trees as a Contribution to Poverty Reduction. Forests, Trees and Livelihoods.16: $35-51$.

Shackleton CM, Shackleton SE (2004) "The importance of non-timber forest products in rural livelihood security and as safety nets: a review of evidence from South Africa. South African Journal of Science. 100 (11 \& 12):658-664.

Sundriyal M, Sundriyal RC, Sharma E (2004) Dietary use of wild plant resources in the Sikkim Himalaya, India. Economic Botany. 58(4): 626-638 available from: ISI:000227297600012.

Syampungani S, Chirwa W, Akinnifesi FK, Sileshi G, Ajayi OC (2009) The miombo

Woodlands at the cross roads: Potential threats, sustainable livelihoods, policy gaps and challenges. Natural Resources Forum. 33 (2):150-159

Tabuti JRS, Dhillion SS, Lye KA (2003) Firewood use in Bulamogi Sub County, Uganda. Species selection, harvesting and Consumption Patterns. Biomass and Bio-energy. 25:581-596.

Tchiegang-Megueni C, Mapongmetsem PM, Akagou Zedong CH, Kapseu C (2001) An Ethnobotanical Study Of Indigenous Fruit Trees In Northern Cameroon. Forests, Trees and Livelihood. 11:149-158.

Ugese FD, Baiyeri KP, Mbah BN (2010) Proximate traits of the seed and cake of Shea butter tree (Vitellaria paradoxa C.F. Gaertn.) in Nigeria's savanna ecozone. Journal of applied Bioscience. 31:1935-1941.

Van der SC, Prehsler S, Hartl A, Vogl CR (2011) Tamarind (Tamarindus indica L.) in the traditional West African diet: not just a famine food. Fruits. 66(3): 171-8.

Yédomonhan H, Houenon GJ, Akoègninou A, Adomou AC, Tossou G, Van der Maesen LJG (2012) The woody flora and its importance for honey production in the Sudano Guinean zone in Benin. International Journal of Science and Advanced Technology. 2221-8386. 